\title{
KOMPARASI MODEL PEMBELAJARAN PROBLEM BASED LEARNING DAN DISCOVERY LEARNING DITINJAU DARI PENINGKATAN KEMAMPUAN PEMECAHAN MASALAH MATEMATIKA SISWA SD
}

\author{
Arfiana Wahyu Kartika ${ }^{1}$, Nyoto Harjono ${ }^{2}$ \\ ${ }^{1,2}$ Universitas Kristen Satya Wacana - J1. Diponegoro No. 52-60 Salatiga, 50711, Indonesia \\ 292016097@student.uksw.edu',nyoto.harjono@uksw.edu²
}

\begin{abstract}
This study aims to prove whether or not there are significant differences between of the models of Problem Based Learning (PBL) and Discovery Learning (DL) in terms of increasing the mathematical problem solving abilities of elementary school students. This study is included in meta-analysis research. Based on the data analysis results, the models of PBL increased an average of $19,56 \%$ greater than DL of $19,01 \%$. Ancova test results show that there is a significant difference between PBL and DL in terms of mathematical problem solving abilities.
\end{abstract}

Keywords: problem based learning, discovery learning, problem solving skill, mathematic

\begin{abstract}
Abstrak: Penelitian ini bertujuan membuktikan ada tidaknya perbedaan signifikan antara model pembelajaran Problem Based Learning (PBL) dan Discovery Learning $(D L)$ ditinjau dari peningkatan kemampuan pemecahan masalah matematika siswa SD. Penelitian ini termasuk dalam penelitian meta analisis. Berdasarkan hasil analisis data, model pembelajaran $P B L$ mengalami peningkatan rata-rata sebesar 19,56\% lebih besar dari model pembelajaran $D L$ sebesar $19,01 \%$. Hasil uji Ancova menunjukkan bahwa terdapat perbedaan yang signifikan antara $P B L$ dan $D L$ ditinjau dari peningkatan kemampuan pemecahan masalah matematika.
\end{abstract}

Kata kunci: problem based learning, discovery learning, pemecahan masalah, matematika

Memasuki abad ke-21, sistem pendidikan nasional menghadapi tantangan dalam menyiapkan kualitas sumber daya manusia (SDM) untuk bersaing di era global. Salah satu tantangan yang dihadapi dunia pendidikan adalah belum berhasilnya meningkatkan SDM di lingkungan pendidikan baik pada pihak pendidik maupun peserta didik. Hal ini terbukti dari rendahnya peringkat Indonesia berdasarkan penilaian PISA dalam pencapaian kemampuan di bidang Matematika dan Membaca pada tahun 2018. Di bidang matematika Indonesia menduduki peringkat 73 dari 79 negara, sedangkan kemampuan membaca berada pada peringkat 74 dari 79 negara (Tohir, 2019). Fakta ini membuktikan bahwa proses pembelajaran di Indonesia khususnya pada bidang matematika masih belum berhasil.

Rendahnya kemampuan siswa dalam bidang matematika juga dinyatakan oleh beberapa hasil penelitian, antara lain sesuai dengan hasil penelitian yang dilakukan Fitra Surya (2017) yang menjelaskan bahwa siswa yang tuntas mencapai KKM 65 sebesar 48\%. Hal ini sejalan dengan penelitian yang dilakukan oleh Suarni (2019) yang menjelaskan bahwa siswa yang tuntas mencapai 
KKM 65 sebesar 45\%. Salah satu kemampuan matematis yang dinilai kurang adalah kemampuan dalam memecahkan masalah matematika. Kenyataan ini juga dinyatakan melalui beberapa hasil penelitian, misalnya hasil penelitian yang dilakukan Putri \& Wahyudi (2020) yang menjelaskan bahwa rata-rata nilai tes kemampuan pemecahan masalah matematika pada saat pretest sebesar $69,43 \%$.

Menurut beberapa hasil penelitian, rendahnya kemampuan pemecahan masalah matematika di lingkungan siswa antara lain disebabkan oleh pembelajaran yang berpusat pada guru. Salah satunya adalah pembelajaran yang tidak mengajak siswa untuk berlatih memecahkan masalah matematika dan model pembelajaran yang digunakan guru kurang cocok untuk dapat menggali kemampuan pemecahan masalah pada diri siswa (Fitriani \& Maulana, 2016). Menurut hasil penelitian yang dilakukan oleh Zulyadaini (2017) bahwa mayoritas guru masih cenderung menggunakan model pembelajaran konvensional. Jelas bahwa model-model yang konvensional itu tidak memberi pengalaman langsung kepada siswa untuk memecahkan masalah-masalah matematika. Kemampuan pemecahan masalah menjadi sangat penting dan salah satu tujuan dalam pembelajaran matematika di sekolah, yakni untuk melatih cara berpikir dan bernalar siswa untuk membuat kesimpulan. Kemampuan pemecahan masalah menurut Polya menyatakan ada 4 langkah penyelesaian, yaitu: 1) memahami masalah, 2) merencanakan penyelesaian, 3) melaksanakan rencana penyelesaian, dan 4) mengecek kembali (Wahyudi \& Anugraheni, 2017). Oleh sebab itu, perlu dipilih model pembelajaran yang langsung mengajak siswa berlatih memecahkan masalahmasalah matematika. Model pembelajaran yang memiliki karakteristik seperti itu antara lain adalah $P B L$ dan $D L$.

Model pembelajaran $P B L$ adalah suatu model pembelajaran yang melibatkan masalah kepada siswa untuk belajara (Agustian, 2018). Siswa dituntut untuk berperan aktif dalam proses pembelajaran dan melatih keterampilan siswa dalam memecahkan suatu permasalahan matematika. Langkah-langkah model pembelajaran $P B L$ ada 5, yaitu: 1) orientasi siswa pada masalah, 2) mengorganisasikan siswa untuk belajar, 3) membimbing pengalaman individual/kelompok, 4) mengembangkan dan menyajikan hasil, serta 5) menganalisis dan mengevaluasi proses pemecahan masalah (Rusman, 2010). Selain model pembelajaran $P B L$, terdapat model pembelajaran $D L$. Model pembelajaran $D L$ adalah model pembelajaran yang memposisikan guru sebagai fasilitator, sehingga siswa menemukan sendiri pengetahuan yang belum diketahui dibimbing oleh pertanyaan yang guru berikan (Mawaddah \& Maryanti, 2016). Model pembelajaran DL menggunakan masalah yang dihadapi siswa adalah semacam masalah yang telah dirancang oleh guru. Sehingga memberi kesempatan siswa untuk menuangkan ide-idenya dengan gaya belajar yang diinginkannya untuk memecahkan masalah matematika. Langkah-langkah model pembelajaran $D L$ ada 6, yaitu: 1) stimulus, 2) problem statement, 3) data collection, 4) data processing, 5) verification, dan 6) generalization (Lestari, 2018). Model pembelajaran $P B L$ dan $D L$ keduanya menggunakan keadaan yang berhubungan dengan kehidupan sehari-hari, sehingga pengetahuan siswa akan tertanam dalam diri siswa tersebut. Dengan menggunakan model pembelajaran $P B L$ dan $D L$ menggunakan permasalahan pada pembelajaran sehingga dapat meningkatkan kemampuan pemecahan masalah matematika. Penelitian yang dilakukan oleh Gunantara, Suarjana, \& Riastini (2014) dengan menggunakan model pembelajaran $P B L$ dapat meningkatkan kemampuan pemecahan masalah matematika. Penelitian yang dilakukan oleh Supriyanto (2014) dengan menggunakan model pembelajaran $D L$ dapat meningkatkan kemampuan pemecahan masalah matematika.

Dari penelitian yang dilakukan menggunakan model pembelajaran $P B L$ dan $D L$, sehingga menimbulkan keragu-raguan apakah terdapat perbedaan penggunaan model pembelajaran $P B L$ dan $D L$ ditinjau dari peningkatan kemampuan pemecahan masalah matematika. Maka dari itu, peneliti 
melakukan penelitian dengan judul "Komparasi Model Pembelajaran Problem Based Learning dan Discovery Learning Ditinjau dari Peningkatan Kemampuan Pemecahan Masalah Matematika Siswa SD”. Penelitian ini dilakukan dengan tujuan untuk membuktikan peningkatan kemampuan pemecahan masalah matematika pada model pembelajaran $P B L$ dan $D L$ pada siswa SD.

\section{METODE}

Penelitian ini menggunakan metode meta analisis. Meta analisis merupakan penelitian yang dilakukan dengan cara merangkum data, mereview, dan menganalisis hasil data. Berdasarkan hasil penelusuran, peneliti memperoleh 20 artikel yang relevan. Pengumpulan data penelitian dilakukan dengan cara mencari artikel-artikel yang terdapat pada jurnal online dengan menggunakan Google Cendikia. Kata kunci yang dipakai untuk mencari artikel adalah "Problem Based Learning", "Discovery Learning", dan "Kemampuan Pemecahan Masalah Matematika". Dari pencarian menggunakan kata kunci tersebut diperoleh beberapa artikel. Artikel yang memenuhi kriteria penelitian yang akan digunakan sebagai data adalah yang terdapat data sebelum perlakuan dan sesudah diberikan perlakuan dalam bentuk skor persentase rata-rata. Instrumen penelitian yang digunakan adalah lembar kerja coding sebagai sarana menghimpun data atas masing-masing artikel yang didapatkan. Lembar kerja coding digunakan untuk mempermudah pengumpulan dan analisis data, sehingga variabel-variabel yang dipakai untuk pemberian kode dan menghasilkan informasi yang dibutuhkan adalah nomor kode, judul penelitian, nama peneliti, tahun terbit, dan variabel bebas yang digunakan.Teknik analisis data menggunakan uji prasyarat (uji normalitas, uji homogenitas, dan uji linearitas), uji Ancova menggunakan Univariate, dan menghitung Effect Size untuk mengetahui besar pengaruh model pembelajaran $P B L$ dan $D L$ terhadap kemampuan pemecahan masalah matematika.

\section{HASIL}

Tahapan awal yang dilakukan dalam penelitian ini adalah merumuskan masalah dan mengumpulkan data penelitian melalui pencarian jurnal elektronik. Berdasarkan hasil penelusuran oleh peneliti diperoleh 20 artikel yang relevan, yaitu 10 artikel model pembelajaran $P B L$ dan 10 artikel model pembelajaran $D L$. Data perolehan skor pembelajaran melalui model $P B L$ disajikan melalui tabel 1 sebagai berikut.

Tabel 1. Persentase Peningkatan Kemampuan Pemecahan Masalah Matematika dengan Model Pembelajaran $P B L$

\begin{tabular}{ccccc}
\hline \multirow{2}{*}{ No. } & \multirow{2}{*}{ Kode Data } & \multicolumn{3}{c}{ Persentase (\%) } \\
\cline { 3 - 5 } & & Skor Pretest & Skor Posttest & Peningkatan \\
\hline 1. & $1 \mathrm{P}$ & 63,5 & 84,25 & 20,75 \\
2. & $2 \mathrm{P}$ & 49,78 & 75,66 & 25,88 \\
3. & $3 \mathrm{P}$ & 62,87 & 84,43 & 21,56 \\
4. & $4 \mathrm{P}$ & 66 & 83,54 & 17,54 \\
5. & $5 \mathrm{P}$ & 39,475 & 68 & 28,525 \\
6. & $6 \mathrm{P}$ & 67,32 & 81,23 & 13,91 \\
7. & $7 \mathrm{P}$ & 69,43 & 81,50 & 12,07 \\
8. & $8 \mathrm{P}$ & 64,30 & 82,86 & 18,56 \\
9. & $9 \mathrm{P}$ & 41,33 & 61,77 & 20,44 \\
10. & $10 \mathrm{P}$ & 70 & 86,42 & 16,42 \\
& Rata-rata & 59,40 & 78,96 & 19,56 \\
\hline
\end{tabular}

Berdasarkan tabel 1 dapat dilihat bahwa persentase rata-rata peningkatan kemampuan pemecahan masalah matematika dengan model pembelajaran $P B L$ dari skor terendah sebesar 13,91\% 
dan skor tertinggi sebesar 28,52\% dengan rata-rata sebesar 19,56\%. Data perolehan skor pembelajaran melalui model $D L$ disajikan melalui tabel 2 sebagai berikut.

Tabel 2. Persentase Peningkatan Kemampuan Pemecahan Masalah Matematika dengan Model Pembelajaran $D L$

\begin{tabular}{ccccc}
\hline \multirow{2}{*}{ No. } & \multirow{2}{*}{ Kode Data } & \multicolumn{3}{c}{ Persentase (\%) } \\
\cline { 3 - 5 } & & Skor Pretest & Skor Posttest & Peningkatan \\
\hline 1. & 1D & 63,33 & 80 & 16,67 \\
2. & 2D & 70,6 & 82,5 & 11,9 \\
3. & 3D & 68,6 & 83,5 & 14,9 \\
4. & 4D & 66 & 73 & 7 \\
5. & 5D & 54,57 & 83,3 & 28,73 \\
6. & 6D & 17,407 & 21,222 & 3,815 \\
7. & 7D & 68,18 & 85,71 & 17,53 \\
8. & 8D & 54,95 & 70,13 & 15,18 \\
9. & 9D & 3,68 & 67,11 & 63,43 \\
10. & 10D & 63,22 & 74,19 & 10,97 \\
& Rata-rata & 53,05 & 72,06 & 19,01 \\
\hline
\end{tabular}

Berdasarkan tabel 2 dapat dilihat bahwa persentase rata-rata peningkatan kemampuan pemecahan masalah matematika dengan model pembelajaran $D L$ dari skor terendah sebesar $7 \%$, skor tertinggi sebesar 63,43\% dengan rata-rata sebesar 19,01\%. Berdasarkan persentase skor pretest dan posttest maka dapat dikomparasikan antara model pembelajaran $D B L$ dan $D L$. Hasil komparasi dapat dilihat pada tabel 3 sebagai berikut.

Tabel 3. Komparasi Hasil Pengukuran Kemampuan Pemecahan Masalah

\begin{tabular}{cccc}
\hline \multirow{2}{*}{ Pengukuran } & \multicolumn{2}{c}{ Rata-Rata Skor (Mean) } & \multirow{2}{*}{ Selisih } \\
\cline { 2 - 3 } & Problem Based Learning & Discovery Learning & \\
\hline Pretest & $59,40 \%$ & $53,05 \%$ & $6,35 \%$ \\
Posttest & $78,96 \%$ & $72,06 \%$ & $6,9 \%$ \\
\hline
\end{tabular}

Berdasarkan hasil komparasi pada tabel 3 dapat dilihat bahwa terdapat perbedaan selisih ratarata skor pretest menggunakan model pembelajaran $P B L$ dan $D L$ sebesar 6,35\%. Sedangkan selisih rata-rata skor posttest menggunakan model pembelajaran $P B L$ dan $D L$ sebesar 6,9\%. Diagram komparasi data antara model pembelajaran $P B L$ dan $D L$ dapat dilihat pada gambar 1.

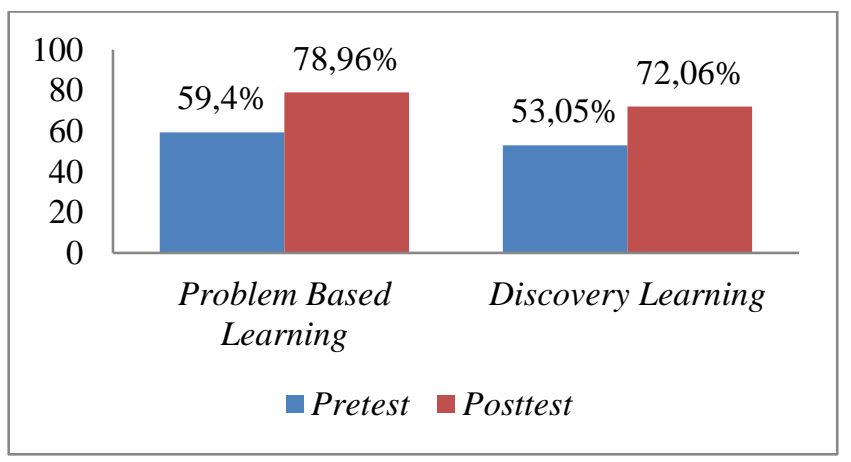

Gambar 1. Diagram Komparasi Data Menggunakan Model Pembelajaran $P B L$ dan $D L$

Berdasarkan gambar 1 dapat dilihat bahwa skor rata-rata kemampuan pemecahan masalah pada model pembelajaran $P B L$ dan $D L$ mengalami peningkatan. Model pembelajaran $P B L$ mengalami peningkatan dari $59,4 \%$ menjadi $78,96 \%$ dan model pembelajaran $D L$ mengalami 
peningkatan dari $53,05 \%$ menjadi $72,06 \%$. Peningkatan yang lebih signifikan terdapat pada model pembelajaran $P B L$.

Tabel 4. Uji Normalitas Model Pembelajaran $P B L$ dan $D L$

\begin{tabular}{llrrrrrr}
\hline & Kelas & \multicolumn{3}{c}{ Kolmogorov-Smirnov $^{\mathbf{a}}$} & \multicolumn{3}{c}{ Shapiro-Wilk } \\
\cline { 3 - 8 } & & Statistic & Df & Sig. & Statistic & df & Sig. \\
\hline \multirow{3}{*}{ Hasil Belajar } & Pretest Problem Based Learning &, 168 & 10 &, $200^{*}$ &, 936 & 10 &, 514 \\
Matematika & Posttest Problem Based Learning &, 243 & 10 &, 097 &, 903 & 10 &, 239 \\
& Pretest Discovery Learning &, 172 & 10 &, $200^{*}$ &, 897 & 10 &, 201 \\
& Posttest Discovery Learning &, 181 & 10 &, $200^{*}$ &, 870 & 10 &, 101 \\
\hline
\end{tabular}

*. This is a lower bound of the true significance.

a. Lilliefors Significance Correction

Berdasarkan tabel 4 dapat dilihat bahwa hasil uji normalitas pretest dan posttest model pembelajaran $P B L$ dan DL. Uji normalitas menggunakan data Shapiro-Wilk berbantuan SPSS 20.0 for windows dengan nilai signifikasi $>0,05$ maka data berdistribusi normal.

Tabel 5. Uji Homogrnitas Skor Pretest Model Pembelajaran $P B L$ dan $D L$

\begin{tabular}{llrrrr}
\hline & & Levene Statistic & df1 & df2 & \multicolumn{1}{l}{ Sig. } \\
\hline \multirow{3}{*}{ Hasil Belajar } & Based on Mean & 2,229 & 1 & 18 &, 153 \\
Matematika & Based on Median &, 768 & 1 & 18 &, 392 \\
& Based on Median and with adjusted df &, 768 & 1 & 12,356 &, 398 \\
& Based on trimmed mean & 1,505 & 1 & 18 &, 236 \\
\hline
\end{tabular}

Berdasarkan tabel 5 dapat dilihat hasil uji homogenitas skor pretest menggunakan metode Levene's Test dengan hasil rata-rata (Based on Mean) menunjukkan nilai Sig. 0,153 > 0,05 sehingga dapat disimpulkan bahwa data berdistribusi homogen.

Tabel 6. Uji Homogenitas Skor Posttest Model Pembelajaran PBL dan DL

\begin{tabular}{llrrrr}
\hline & & Levene Statistic & df1 & \multicolumn{1}{c}{ df2 } & \multicolumn{1}{l}{ Sig. } \\
\hline & Based on Mean & 1,187 & 1 & 18 &, 290 \\
Hasil Belajar & Based on Median & 1,047 & 1 & 18 &, 320 \\
Matematika & Based on Median and with adjusted df & 1,047 & 1 & 12,098 &, 326 \\
& Based on trimmed mean &, 928 & 1 & 18 &, 348 \\
\hline
\end{tabular}

Berdasarkan tabel 6 dapat dilihat bahwa hasil uji homogenitas skor posttest menggunakan metode Levene's Test dengan hasil rata-rata (Based on Mean) menunjukkan nilai Sig. 0,290 > 0,05 sehingga dapat disimpulkan bahwa data berdistribusi homogen.

Tabel 7. Uji Linearitas Skor Pretest dan Posttest Model Pembelajaran PBL

\begin{tabular}{|c|c|c|c|c|c|c|c|}
\hline & & & $\begin{array}{c}\text { Sum of } \\
\text { Squares }\end{array}$ & df & $\begin{array}{c}\text { Mean } \\
\text { Square }\end{array}$ & $\mathbf{F}$ & Sig. \\
\hline \multirow{5}{*}{$\begin{array}{l}\text { Posttest * } \\
\text { Pretest }\end{array}$} & \multirow{3}{*}{ Between Groups } & (Combined) & 586,889 & 8 & 73,361 & 75,939 & ,089 \\
\hline & & Linearity & 510,224 & 1 & 510,224 & 528,155 & ,028 \\
\hline & & Deviation from Linearity & 76,664 & 7 & 10,952 & 11,337 & ,225 \\
\hline & Within Groups & & ,966 & 1 & ,966 & & \\
\hline & Total & & 587,855 & 9 & & & \\
\hline
\end{tabular}


Berdasarkan tabel 7 dapat dilihat bahwa hasil uji linearitas skor pretest dan posttest model pembelajaran $P B L$ dengan menggunakan Deviation from Linearity menunjukkan nilai Sig. 0,225 > 0,05 sehingga dapat disimpulkan bahwa data memiliki hubungan yang linear.

Tabel 8. Uji Linearitas Skor Pretest dan Posttest Model Pembelajaran DL

\begin{tabular}{|c|c|c|c|c|c|c|c|}
\hline & & & $\begin{array}{l}\text { Sum of } \\
\text { Squares }\end{array}$ & df & $\begin{array}{c}\text { Mean } \\
\text { Square }\end{array}$ & $\mathbf{F}$ & Sig. \\
\hline \multirow{5}{*}{$\begin{array}{l}\text { Posttest * } \\
\text { Pretest }\end{array}$} & \multirow{3}{*}{ Between Groups } & (Combined) & 3216,843 & 8 & 402,105 & 23,824 & 157 \\
\hline & & Linearity & 699,635 & 1 & 699,635 & 41,452 & ,098 \\
\hline & & Deviation from Linearity & 2517,207 & 7 & 359,601 & 21,306 & , 165 \\
\hline & Within Groups & & 16,878 & 1 & 16,878 & & \\
\hline & Total & & 3233,721 & 9 & & & \\
\hline
\end{tabular}

Berdasarkan tabel 8 dapat dilihat bahwa hasil uji linearitas skor pretest dan posttest model pembelajaran $D L$ dengan menggunakan Deviation from Linearity menunjukkan nilai Sig. 0,165 > 0,05 sehingga dapat disimpulkan bahwa data memiliki hubungan yang linear.

Tabel 9. Hasil Analisis Data Menggunakan Uji Ancova

\begin{tabular}{lcrr}
\multicolumn{2}{l}{ Dependent Variable: Hasil Posttest } & & \\
\hline Model Pembelajaran & Mean & Std. Deviation & N \\
\hline Problem Based Learning & 78,9660 & 8,08191 & 10 \\
Discovery Learning & 65,6610 & 6,52881 & 10 \\
Total & 72,3135 & 9,88512 & 20 \\
\hline
\end{tabular}

Berdasarkan tabel 9 dapat dilihat bahwa hasil analisis data menggunakan uji Ancova yang dilakukan pada model pembelajaran $P B L$ dengan jumlah artikel sebanyak 10 dengan rata-rata 78,9660 . Sedangkan pada model pembelajaran $D L$ dengan jumlah artikel sebanyak 10 mempunyai rata-rata 65,6610. Sehingga terdapat perbedaan antara model pembelajaran $P B L$ dan $D L$ ditinjau dari peningkatan kemampuan pemecahan masalah matematika. Model pembelajaran $P B L$ hasilnya lebih tinggi dibandingkan model pembelajaran $D L$.

Tabel 10. Hasil Analisis Uji Ancova

\begin{tabular}{lcrrrrr}
\hline Dependent Variable: Nilai Postest & $\begin{array}{c}\text { Type III Sum } \\
\text { of Squares }\end{array}$ & df & \multicolumn{1}{c}{$\begin{array}{c}\text { Mean } \\
\text { Square }\end{array}$} & F & Sig. & $\begin{array}{c}\text { Partial Eta } \\
\text { Squared }\end{array}$ \\
\hline Corrected Model & $885,115^{\mathrm{a}}$ & 1 & 885,115 & 16,400 &, 001 &, 477 \\
Intercept & 104584,846 & 1 & 104584,846 & 1937,788 &, 000 &, 991 \\
Model_Pembelajaran & 885,115 & 1 & 885,115 & 16,400 &, 001 &, 477 \\
Error & 971,483 & 18 & 53,971 & & & \\
Total & 106441,443 & 20 & & & & \\
Corrected Total & 1856,598 & 19 & & & &
\end{tabular}

Berdasarkan tabel 10 dapat dilihat hasil uji Ancova yang terletak pada kolom Model Pembelajaran di atas diperoleh signifikasi pada kolom Sig. sebesar 0,001 yang berarti lebih kecil dari $0,05(0,001<0,05)$ menunjukkan bahwa $\mathrm{H}_{\mathrm{o}}$ ditolak dan $\mathrm{H}_{\mathrm{a}}$ diterima. Hal ini dapat disimpulkan bahwa terdapat perbedaan yang signifikan dalam penggunaan model pembelajaran $P B L$ dan $D L$ ditinjau dari peningkatan kemampuan pemecahan masalah matematika siswa SD.

Besarnya pengaruh dari penggunaan model pembelajaran $P B L$ dan $D L$ ditinjau dari peningkatan kemampuan pemecahan masalah matematika dapat diketahui ukuran pengaruhnya dengan uji Effect Size. Berikut ini adalah interperensi Effect Size pada tabel 11. 
Tabel 11. Interpretasi Effect Size

\begin{tabular}{cc}
\hline Effect Size & Interpretasi \\
\hline $0<\mathrm{d}<0,2$ & Kecil \\
$0,2<\mathrm{d} \leq 0,5$ & Sedang \\
$0,5<\mathrm{d} \leq 0,8$ & Besar \\
$\mathrm{d}>0,8$ & Sangat Besar \\
\hline
\end{tabular}

Berikut ini adalah hasil analisis Effect Size yang dilakukan untuk melihat pengaruh model pembelajaran $P B L$ dan $D L$ untuk meningkatkan kemampuan pemecahan masalah matematika.

Tabel 12. Hasil Uji Effect Size menggunakan Uji Ancova

\begin{tabular}{lrrrrrr}
\hline Dependent Variable: Nilai Postest & $\begin{array}{c}\text { Type III Sum } \\
\text { of Squares }\end{array}$ & df & $\begin{array}{c}\text { Mean } \\
\text { Square }\end{array}$ & F & Sig. & $\begin{array}{c}\text { Partial Eta } \\
\text { Squared }\end{array}$ \\
\hline Corrected Model & $885,115^{\mathrm{a}}$ & 1 & 885,115 & 16,400 &, 001 &, 477 \\
Intercept & 104584,846 & 1 & 104584,846 & 1937,788 &, 000 &, 991 \\
Model_Pembelajaran & 885,115 & 1 & 885,115 & 16,400 &, 001 &, 477 \\
Error & 971,483 & 18 & 53,971 & & & \\
Total & 106441,443 & 20 & & & & \\
Corrected Total & 1856,598 & 19 & & & &
\end{tabular}

Berdasarkan tabel 12 dapat dilihat bahwa uji Effect Size menggunakan uji Ancova pada model pembelajaran $P B L$ dan $D L$ terdapat hasil yang tertera pada kolom Corrected Model yang diketahui Partical Eta Squared sebesar 0,477 dengan nilai Sig. sebesar 0,001. Hal ini menunjukkan bahwa model pembelajaran $P B L$ dan $D L$ memberikan pengaruh tergolong sedang terhadap kemampuan pemecahan masalah matematika.

\section{PEMBAHASAN}

Penelitian ini dilakukan untuk membuktikan ada tidaknya perbedaan signifikan antara model pembelajaran $P B L$ dan $D L$ ditinjau dari peningkatan kemampuan pemecahan masalah matematika siswa SD. Hasil kajian efektivitas dari kedua model pembelajaran, dilakukan untuk menguji hipotesis. Uji hipotesis dilakukan untuk menentukan apakah hipotesis diterima atau ditolak. $\mathrm{H}_{\mathrm{o}}$ berarti bahwa tidak terdapat perbedaan yang signifikan antara penggunaan model pembelajaran $P B L$ dan $D L$ ditinjau dari peningkatan kemampuan pemecahan masalah matematika siswa SD. Sedangkan $\mathrm{H}_{\mathrm{a}}$ berarti bahwa terdapat perbedaan yang signifikan antara penggunaan model pembelajaran $P B L$ dan $D L$ ditinjau dari peningkatan kemampuan pemecahan masalah matematika siswa SD.

Berdasarkan hasil perhitungan hipotesis dengan melakukan uji Ancova menggunakan Univariate pada tabel 10 yang menunjukkan bahwa nilai signifikasi sebesar 0,001 yang berarti lebih kecil dari $0,05(0,001<0,05)$ yang menunjukkan bahwa $\mathrm{H}_{\mathrm{o}}$ ditolak dan $\mathrm{H}_{\mathrm{a}}$ diterima. Dengan demikian terdapat perbedaan yang signifikan antara menggunakan model pembelajaran $P B L$ dan $D L$ ditinjau dari peningkatan kemampuan pemecahan masalah matematika siswa SD. Meskipun kedua model pembelajaran tersebut dapat meningkatkan kemampuan pemecahan masalah matematika, ternyata model pembelajaran $P B L$ lebih efektif dibandingkan dengan model pembelajaran $D L$. Hal ini dapat dilihat pada tabel 9 bahwa nilai rata-rata skor posttest model pembelajaran $P B L$ sebesar 78,9660 lebih tinggi dibandingkan model pembelajaran $D L$ sebesar 65,6610. 
Melalui perbandingan data perolehan skor dari kedua model tersebut, ternyata $P B L$ lebih tinggi $19,56 \%$ dibanding perolehan data skor $D L 19,01 \%$. Dengan demikian dapat disimpulkan bahwa model pembelajaran $P B L$ lebih efektif untuk meningkatkan kemampuan pemecahan masalah matematika dibandingkan dengan model pembelajaran $D L$. Hasil ini memperkuat penelitian yang dilakukan oleh Susilowati (2020) yang menunjukkan bahwa kemampuan pemecahan masalah matematika dapat ditingkatkan melalui penerapan model pembelajaran $P B L$. Sejalan dengan penelitian yang dilakukan oleh Indarwati, Wahyudi, \& Ratu (2014) yang menunjukkan bahwa menggunakan model pembelajaran $P B L$ berpengaruh terhadap kemampuan pemecahan masalah matematika siswa. Penelitian yang dilakukan oleh Nasir (2016) yang menunjukkan bahwa model pembelajaran $P B L$ dapat meningkatkan kemampuan pemecahan masalah matematika siswa.

Setelah melakukan uji hipotesis, selanjutnya menghitung Effect Size dari kedua model pembelajaran terdapat pada tabel 12 yang diketahui bahwa Partical Eta Squared sebesar 0,477 dengan Sig. sebesar 0,001. Hal ini menunjukkan bahwa model pembelajaran $P B L$ dan $D L$ memberikan pengaruh tergolong sedang terhadap kemampuan pemecahan masalah matematika.

\section{SIMPULAN}

Berdasarkan hasil dan pembahasan yang telah dijabarkan, dapat disimpulkan bahwa model pembelajaran Problem Based Learning lebih efektif dalam meningkatkan kemampuan pemecahan masalah matematika dibanding model pembelajaran Discovery Learning. Hal ini dapat dilihat melalui uji Ancova dengan nilai rata-rata skor posttest model pembelajaran Problem Based Learning sebesar 78,9660 lebih tinggi dibanding dengan model pembelajaran Discovery Learning sebesar 65,6610. Selain itu berdasarkan perhitungan uji Effect Size menunjukkan pengaruh yang signifikan dengan nilai Partical Eta Squared sebesar 0,477 sehingga model pembelajaran Problem Based Learning dan Discovery Learning memberikan pengaruh tergolong sedang terhadap kemampuan pemecahan masalah matematika.

\section{DAFTAR RUJUKAN}

Agustian, H. (2018). Penggunaan Model Problem Based Learning untuk Meningkatkan Rasa Percaya Diri dan Hasil Belajar Siswa pada Sub Tema Pelestarian Kekayaan Sumber Daya Alam di Indonesia. FKIP UNPAS, 14-47.

Fitra Surya, Y. (2017). Penggunaan Model Pembelajaran Pendidikan Karakter Abad 21 pada Anak Usia Dini. Jurnal Obsesi: Jurnal Pendidikan Anak Usia Dini, 1(1), 52-61. https://doi.org/10.31004/obsesi.v1i1.30

Fitriani, K., \& Maulana. (2016). Meningkatkan Kemampuan Pemahaman dan Pemecahan Masalah Matematis Ssiswa SD Kelas V Melalui Pendekatan Matematika Realistik. Mimbar Sekolah Dasar, 3(1), 40-52. https://doi.org/10.17509/mimbar-sd.v3i1.2355

Gunantara, G., Suarjana, I. M., \& Riastini, P. N. (2014). Penerapan Model Pembelajaran Problem Based Learning untuk Meningkatkan Kemampuan Pemecahan Masalah Matematika Siswa Kelas V. Jurnal Mimbar PGSD Universitas Pendidikan Ganesha Jurusan PGSD, 2(1).

Indarwati, D., Wahyudi, \& Ratu, N. (2014). Peningkatan Kemampuan Pemecahan Masalah Matematika melalui Penerapan Problem Based Learning untuk Siswa Kelas V SD. Satya Widya, 30(1), 17-27.

Lestari, L. (2018). Penerapan Model Pembelajaran Discovery Learning untuk Meningkatkan Minat dan Hasil Belajar Siswa pada Materi Sejarah. Metafora: Education, Social Sciences and Humanities Journal, 2(2), 1-14.

Mawaddah, S., \& Maryanti, R. (2016). Kemampuan Pemahaman Konsep Matematis Siswa SMP dalam Pembelajaran Menggunakan Model Penemuan Terbimbing (Discovery Learning). Edu-Mat: Jurnal Pendidikan Matematika, 4(1), 76-85. 
Nasir, M. (2016). Efektivitas Model Pembelajaran Berbasis Masalah (Problem Based Learning) Terhadap Kemampun Pemecahan Masalah Siswa pada Pelajaran Matematika. Muallimuna: Jurnal Madrasah Ibtidaiyah, 1(2), 1-19.

Putri, U. A., \& Wahyudi. (2020). Efektivitas Problem Based Learning dan Problem Solving Ditinjau dari Kemampuan Pemecahan Masalah Matematika Peserta Didik Kelas IV SD. Jurnal Edukasi Matematika Dan Sains), 8(1), 69-78. https://doi.org/10.25273/jems.v8i1.6088

Rusman. (2010). Model-Model Pembelajaran: Mengembangkan Profesionalisme Guru. PT Rajagrafindo Persada.

Suarni, E. (2019). Upaya Meningkatkan Hasil Belajar Matematika Siswa Kelas III Dengan Menggunakan Pendekatan Inkuiri Terbimbing di SDN 05 Kota Mukomuko. IJIS Edu: Indonesian Journal of Integrated Science Education, 1(1), 63-70.

Supriyanto, B. (2014). Penerapan Discovery Learning untuk Meningkatkan Hasil Belajar Siswa Kelas VI B Mata Pelajaran Matematika Pokok Bahasan Keliling dan Luas Lingkaran di SDN Tanggul Wetan 02 Kecamatan Tanggul Kabupaten Jember. Pancaran Pendidikan, 3(2), 165174.

Susilowati, R. D. (2020). Efektivitas Model Pembelajaran Inquiry dan Problem Based Learning Terhadap Kemampuan Pemecahan Masalah pada Mata Pelajaran Matematika Kelas IV SD. Jurnal Edukasi Matematika Dan Sains), 8(1), 49-59. https://doi.org/10.25273/jems.v8i1.6084

Tohir, M. (2019). Hasil PISA Indonesia Tahun 2018 Turun Dibanding Tahun 2015.

Wahyudi, \& Anugraheni, I. (2017). Strategi Pemecahan Masalah Matematika. Satya Wacana Press. Zulyadaini. (2017). Perbandingan Hasil Belajar Matematika Model Pembelajaran Kooperatif Tipe Coop-Coop dengan Konvensional. Jurnal Ilmiah Universitas Batanghari Jambi, 16(1), 153158. 